\title{
Konservasi Cagar Budaya Kayu Dengan Asap Cair (Uji Lapangan)
}

\author{
Moh. Habibi, Winda Diah P., Rifki K., Heri Yulianto, Wahyudi \\ Balai Konservasi Borobudur \\ Jln Badrawati, Borobudur, Magelang, Jawa Tengah \\ Sur-el : habib1_m@yahoo.com
}

\begin{abstract}
Abstak: Dalam penelitian ini dievaluasi efektivitas asap cair untuk pengawetan kayu pada skala lapangan (graveyard test). Variabel bebas pada kajian ini meliputi konsentrasi asap cair $(0 \%, 10 \%, 20 \%, 30 \%, 50 \%, 100 \%$, Termicon), jenis kayu (Jati \& Nangka), dan teknik aplikasi (oles \& semprot). Variabel terikat yang diamati adalah berat kayu uji dan kualitas mutu kayu (tingkat kerusakan kayu akibat serangan rayap). Pengujian skala lapangan dilakukan dengan mengubur sampel kayu selama dua bulan. Hasil kajian menujukkan bahwa hanya konsentrasi asap cair yang berpengaruh nyata terhadap ketahanan kayu uji dari rayap tanah. Konsentrasi 100\% memberikan pengaruh berbeda nyata dibandingkan dengan konsentrasi yang lain serta memberikan kualitas mutu kayu yang terbaik.
\end{abstract}

Kata kunci : Asap cair, graveyard test, kayu, rayap tanah

\begin{abstract}
This study evaluated the effectiveness of liquid smoke on presevertion of wood samples in field-scale testing (graveyard test). The independent variables in this study consisted of liquid smoke concentrations $(0 \%$, $10 \%, 20 \%, 30 \%, 50 \%, 100 \%$, Termicon), timber species (Teak \& Jackfruit), and application techniques (spraying \& rubing). The observed dependent variables included the weight of the tested wood and the quality of the wood (wood damages due to termite attacks). Field-scale testing was conducted by graveyarding the wood samples for two months. The results showed that only the concentration of liquid smoke had a significant effect on the durability of the test wood from the soil termites. The concentration of $100 \%$ gives a significantly different effect compared to other concentrations and provides the best quality of wood.
\end{abstract}

Keyword : Liquid Smoke, graveyard test, wood, soil termites

\section{A. Latar Belakang}

Indonesia mempunyai benda cagar budaya yang melimpah. Banyak benda cagar budaya yang ditemukan di Indonesia, baik di daratan maupun di laut. Benda cagar budaya yang ditemukan dapat berupa logam, batuan, keramik, dan kayu. Benda peninggalan yang berupa kayu sangat rentan terhadap degradasi/pengerusakan disebabkan karena faktor biologis, kimiawi ataupun fisik. Hal ini disebabkan karena kayu merupakan benda organik yang dengan mudah dapat menarik mikroorganisme dan serangga (Florian, 1997).

Beberapa permasalahan yang sering terjadi pada benda cagar budaya kayu adalah terjadinya kerusakan struktur morfologi dan anatomi dari kayu itu sendiri. Degradasi morfologi dan anatomi disebabkan karena adanya mikroorganisme (fungi) dan penguraian selulosa kayu oleh rayap. Beberapa jenis fungi pada benda cagar budaya kayu yang telah berhasil diidentifikasi adalah dari genus Penicillium sp., Cladosporium sp., Aureobasidium sp., dan Eupenicillium sp., (Ortiz et al., 2014), sedangkan rayap yang umum menyerang kayu adalah rayap kayu kering (Cryptotermes spp.) dan rayap tanah (Macrotermes spp.) (Wijaya et al., 2008).

Usaha konservasi dan preservasi kayu telah banyak dilakukan. Konservasi benda cagar budaya kayu dengan memanfaatkan bahan tradisional sedang banyak dikembangkan karena bahan tradisional lebih aman bagi lingkungan dan manusia. Beberapa bahan tradisional yang telah diuji untuk konservasi benda cagar budaya kayu 
seperti tembakau, cengkeh, dan pelepah pisang terbukti efektif untuk melawan jamur dan rayap (Cahyandaru et al., 2010).

Berdasarkan Wagiman et al. (2014) asap cair dapat digunakan untuk mengawetkan kayu. Asap cair (liquid smoke) merupakan hasil kondensasi atau pengembunan uap hasil pembakaran secara langsung maupun tidak langsung dari bahan-bahan yang banyak mengandung lignin, selulosa, hemiselulosa serta senyawa karbon lainnya (Darmadji, 2002). Bahan baku yang banyak digunakan antara lain berbagai macam jenis kayu, bongkol kelapa sawit, sampah organik, tempurung kelapa, sekam, ampas atau serbuk gergaji kayu dan lain sebagainya. Selama pembakaran, komponen dari kayu akan mengalami pirolisa menghasilkan berbagai macam senyawa antara lain fenol, karbonil, asam, furan, alkohol, lakton, hidrokarbon, polisiclik aromatic dan lain sebagainya (Girrad, 1992). Asap cair mempunyai berbagai sifat fungsional, seperti untuk memberi aroma, rasa dan warna karena adanya senyawa fenol dan karbonil sebagai bahan pengawet alami karena mengandung senyawa fenol dan asam yang berperan sebagai anti bakteri dan antioksidan (Pszczola, 1995). Penelitian asap cair dari batok kelapa sebagai bahan konservasi cagar budaya kayu telah dilakukan oleh Habibi dkk pada tahap I yang dilakukan tahun 2016. Pada kajian tersebut membuktikan asap cair dari batok kelapa dapat menghambat serangan jamur dan rayap.

Sebagai data pembanding kajian asap cair ini, tim kajian melakukan studi observasi ke perkampungan Rantau Panjang, Kabupaten Merangin Jambi. Perkampungan ini terletak di Kecamatan Tabir tepatnya di Desa Rantau Panjang atau sekitar $30 \mathrm{Km}$ dari Bangko. Desa ini merupakan desa tertua di provinsi Jambi yang memiliki rumah-rumah kayu berusia ratusan tahun. Penduduk desa ini adalah suku Batin keturunan proto Melayu atau Melayu tua. Suku Batin sendiri merupakan suku asli Jambi. Di sini terdapat salah satu rumah yang ditempati keluarga yang merupakan keturunan ke 14 dari Puyang Bungkuk pendiri dari desa tersebut (Dusun Tuo Rantau Panjang). Rumah ini merupakan bekas Rumah Raja dan konon satu diantara rumah tertua yang sudah ada sejak tahun 1333. Selain masih dihuni, rumah ini juga dijadikan museum bagi Suku Batin di Dusun Tuo Rantau Panjang. Keunikan yang lain dari rumah tradisional ini yaitu dibangun dengan kayu tanpa paku hanya memakai pasak dan ikat. Rumah tradisional tersebut masih menggunakan perapian kayu bakar di dalam rumah. Sehingga dimungkinkan kayu rumah rumah tersebut terawetkan karena adanya jelaga.

\section{B. Metodologi Penelitian}

\section{Alat}

Alat yang digunakan dalam penelitian ini antara lain beaker glass, gelas ukur, kuas, GC-MS, oven, timbangan digital, linggis, penggaris, kamera, radiator, paint spray.

Bahan

Bahan yang digunakan yaitu kayu Nangka (Artocarpus heterophyllus) dan kayu Jati (Tectona grandis) yang diperoleh dari pengerajin kayu di dekat pasar Borobudur. Asap cair tempurung kelapa yang digunakan berasal dari Fakultas Teknologi Pertanian Universitas Gadjah Mada.

\section{Jenis dan Sumber Data}

Jenis data yang digunakan dalam penelitian ini adalah data kualitatif dan kuantitatif. Data kualitatif diperoleh melalui observasi lapangan cagar budaya kayu yang terawetkan dengan asap di penduduk Merangin. Sedangkan data kuantitatif meliputi kehilangan berat kayu contoh uji.

Sumber data primer yaitu hasil pengujian asap cair terhadap kehilangan berat kayu contoh uji setelah uji kubur. Sumber data sekunder dalam kajian ini berupa artikel, jurnal, dan laporan hasil kajian terdahulu tentang asap cair maupun konservasi kayu.

\section{Metode Pengumpulan Data}

Metode pengumpulan data yang digunakan dalam kajian ini meliputi observasi ke daerah Jambi yang telah menggunakan metode pengasapan untuk mengawetkan cagar budaya kayu, dan melakukan pengamatan secara langsung terhadap pengaruh asap cair terhadap kehilangan berat kayu uji dengan mekanisme uji kubur (graveyard test) serta uji GC-MS untuk mengetahui komposisi asap cair yang digunakan dalam kajian ini. Kondisi GC-MS yang digunakan pada penelitian ini meliputi suhu awal $80 \mathrm{oC}$, laju $10 \mathrm{oC}$, suhu maksimum $320 \mathrm{oC}$ dengan holding time 5 menit. 
Pengujian lapang (graveyard test) dilakukan dengan mengacu pada ASTM D 1758-06 (2006). Contoh uji berukuran panjang x lebar x tebal sebesar $(40 \times 2 \times 2)$ cm3. Ulangan dilakukan sebanyak tiga kali untuk setiap perlakuan. Variabel bebas dalam penelitian ini meliputi konsentrasi asap cair $(0 \%, 10 \%, 20 \%, 30 \%, 50 \%, 100 \%$, control positif), jenis kayu (Nangka \& Jati), dan metode aplikasi (oles dan semprot). Contoh uji dioven pada suhu $(60 \pm 2)$ oC selama 48 jam yang kemudian ditimbang beratnya (Bo). Setelah itu, contoh uji disemprot dengan masing konsentrasi asap cair dan metode aplikasi. Persiapan lapang dilakukan dengan membersihkan area untuk penempatan contoh uji. Contoh uji dikubur secara acak dalam tanah dengan jarak antar contoh uji sebesar $30 \mathrm{~cm}$ serta jarak antar baris sebesar $60 \mathrm{~cm}$. Kedalaman contoh uji yang terkubur adalah $20 \mathrm{~cm}$ dari total panjang contoh uji (gambar 1)

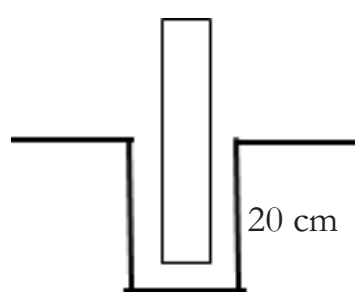

(a)

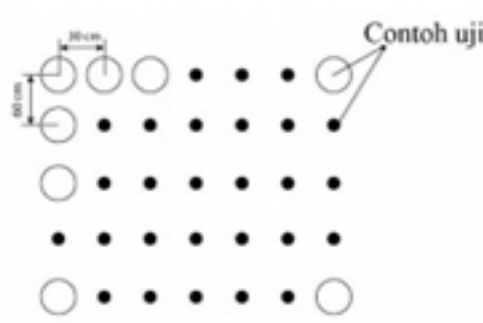

(b)
Gambar 1 posisi contoh uji yang dikubur (a); penempatan contoh uji di lapang (b)

Pengujian dilakukan selama 60 hari. Setelah 60 hari contoh uji diambil dengan posisi tegak dan usahakan tidak ada contoh uji yang patah. Contoh uji dibersihkan dari tanah yang menempel lalu diamati kerusakannya. Selanjutnya contoh uji dikeringkan dalam oven dengan suhu $(60 \pm 2)$ oC selama 48 jam lalu ditimbang (B1). Kehilangan berat contoh uji dihitung dengan menggunakan rumus sebagai berikut:

Kehilangan berat $(\%)=(\mathrm{B} 0-\mathrm{B} 1) / \mathrm{B} 0 \times 100 \%$

Dimana : B0 = Berat contoh uji kering tanur sebelum diumpankan (g)

B1 = Berat contoh uji kering tanur setelah diumpankan (g)

Penentuan kelas mutu kayu mengacu kepada ASTM D 1758-06 (2006) dimana kelas mutu kayu ditentukan berdasarkan persentase hilangnya kayu arah cross section akibat serangan rayap tanah. Contoh uji yang telah diumpankan dan dibersihkan dari tanah, selanjutnya diukur penetrasi serangan rayap pada bagian penampang melintang kayu. Pengukuran dilakukan pada bagian contoh uji yang terserang rayap paling parah. Selanjutnya hitung persentase kehilangan kayu (PL) dengan persamaan berikut:

\begin{tabular}{|c|c|}
\hline Ningi & Kondiai Serngen \\
\hline 10 & 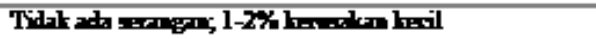 \\
\hline 9 & 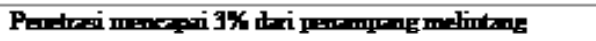 \\
\hline $\mathbf{B}$ & 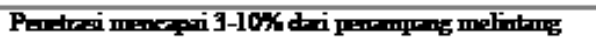 \\
\hline $\mathbf{7}$ & 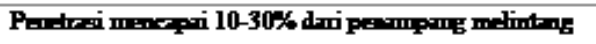 \\
\hline 6 & 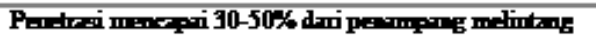 \\
\hline 4 & 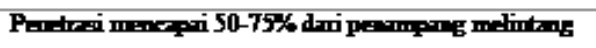 \\
\hline $\mathbf{0}$ & Rosalk \\
\hline
\end{tabular}

Hasil kehilangan persentase tersebut digunakan untuk menentukan kelas mutu kayu terhadap serangan rayap tanah berdasarkan table berikut:

Tabel 1 penilaian kerusakan contoh uji oleh rayap tanah

\section{Analisis Data}

Pada penelitian ini, analisis yang digunakan adalah dengan Faktorial RAL (Rancangan Acak Lengkap) dengan 3 faktor. Hal ini bertujuan untuk mengetahui apakah ada pengaruh dari konsentrasi asap cair, jenis kayu, metode aplikasi, dan interaksi ketiganya terhadap ketahanan kayu pada serangan rayap tanah. Data yang diperoleh diproses dengan menggonakan Microsoft Excel 2013. Faktor A adalah konsentrasi asap cair, faktor $\mathrm{B}$ adalah jenis kayu, dan faktor $\mathrm{C}$ adalah metode aplikasi. Ulangan yang dilakukan sebanyak tiga kali. Model yang digunakan dalam rancangan percobaan ini adalah:

Yijkl $=\mu+\alpha \mathrm{i}+\beta \mathrm{j}+(\alpha \beta) \mathrm{ij}+\gamma \mathrm{k}+(\alpha \gamma) \mathrm{ik}+(\beta \gamma) \mathrm{jk}+$ $(\alpha \beta \gamma)$ ijk + Eijkl

Yijkl merupakan nilai pengamatan pada ulangan ke-l yang disebabkan oleh taraf ke-I faktor $\alpha$, taraf ke-j faktor $\beta$, dan taraf ke-k faktor $\boldsymbol{\gamma}$. i adalah konsentrasi asap cair $(0 \%, 10 \%, 20 \%, 30 \%, 50 \%, 100 \%$, Termicon), j adalah jenis kayu (kayu Nangka dan kayu Jati), k adalah metode aplikasi (Oles dan Semprot), 1 adalah ulangan 1, 2, 3. $(\alpha \beta) \mathbf{i j}$ adalah interaksi antara perlakuan konsentrasi asap cair dan jenis kayu. $(\boldsymbol{\alpha} \boldsymbol{\gamma}) \mathbf{i k}$ adalah interaksi antara 
perlakuan konsentrasi dan metode aplikasi. $(\boldsymbol{\beta} \boldsymbol{\gamma}) \mathbf{j k}$ adalah interaksi antara perlakuan jenis kayu dan metode aplikasi. $(\alpha \beta \gamma) \mathbf{i j k}$ adalah interaksi antara perlakuan asap cair, jenis kayu, dan metode aplikasi. Sedangkan Eijkl galat percobaan untuk pengamatan ke-I, j, k, l.

\section{Hasil Dan Pembahasan}

\section{Komposisi Penyusun Asap Cair Tempurung Kelapa}

Untuk mengetahui komponen kimiawi penyusun asap cair tempurung kelapa pada penelitian ini, dilakukan uji GC-MS (Gas Chromatography-Mass Spectrometry). Pengujian GC-MS asap cair dilakukan di laboratorium terpadu Universitas Islam Indonesia (UII). Hasil GC-MS selengkapnya sebagai berikut:

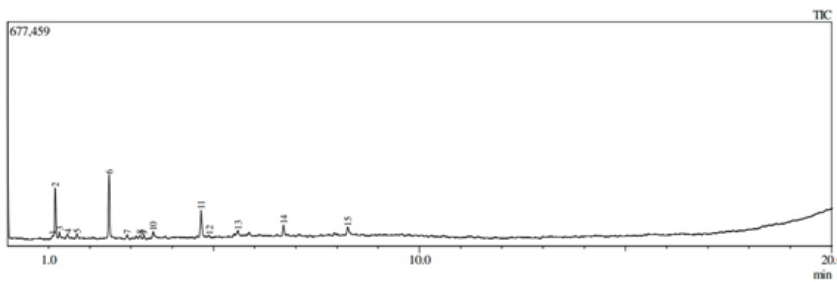

Gambar 2 Kromatorgram asap cair

\section{tempurung kelapa}

Berdasarkan hasil analisis kromatografi gas (Gambar 2), terdapat puncak-puncak kromatogram sebanyak 15 senyawa penyusun asap cair tempurung kelapa grade 3 beserta fraksi massa dan jenis masing-masing senyawa yang dapat dilihat pada tabel 2. Teridentifikasi empat senyawa asam menyebabkan $\mathrm{pH}$ asap cair ini berada pada kisaran 2-3. Adapun \% area terbesar ditunjukkan oleh asam format sebesar 22,76\%. Untuk senyawa fenol, persentase area terbesar ditunjukkan oleh senyawa oxybenzene sebesar $27,55 \%$.

\begin{tabular}{|c|c|c|c|c|}
\hline Na & Nom Selyam & Rmons Bangen & y Area & Walta Ketemei \\
\hline \multirow[t]{2}{*}{$\mathbf{1}$} & 2,5-c,pootadienal & $\mathrm{C}_{\boldsymbol{\gamma}} \mathrm{H}_{2} \mathrm{O}$ & 1,73 & 1,092 \\
\hline & Anam & & & \\
\hline 2 & Asem Famat & $\mathrm{C}_{2} \mathrm{H}_{2} \mathrm{O}_{2}$ & 22,76 & 1,161 \\
\hline $\mathbf{3}$ & Asem Frupamat & $\mathrm{C}_{2} \mathrm{H}_{6} \mathrm{O}_{2}$ & 3,29 & 1,261 \\
\hline 4 & Asmm B-inat & $C \mathrm{H}_{2}, \mathrm{O}_{3}$ & 1,Bs & 3,219 \\
\hline 5 & Asem Herond & $\mathrm{C}_{\mathrm{H}_{2} \mathrm{H}_{2} \mathrm{O}_{2}}$ & 5,66 & 8,260 \\
\hline 6 & 3Pentanone & $\mathrm{C}_{2} \mathrm{H}_{4} \mathrm{O}$ & $2, \mathbf{B 1}$ & 1,459 \\
\hline \multirow[t]{2}{*}{7} & Pyrame & $\mathrm{C}_{3} \mathrm{H}_{4} \mathrm{~N}_{2}$ & 2,08 & 1,688 \\
\hline & Fod & & & \\
\hline B & Oxyberente & $\mathrm{C}_{8} \mathrm{H}_{8} \mathrm{O}$ & 27,55 & 2,467 \\
\hline 9 & Creol & C:H & $1, \pi 7$ & 3,314 \\
\hline 14 & Graianol & $\mathrm{C}_{\mathrm{H}} \mathrm{H}_{\mathrm{O}}$ & 2,26 & 3,53B \\
\hline $\mathbf{u}$ & Hydmoquinene & $\mathrm{C}_{8} \mathrm{H}_{6} \mathrm{O}_{2}$ & 15,62 & 4,699 \\
\hline 12 & Indadyric mlythic & $\mathrm{C}_{\mathrm{H}_{3}} \mathrm{O}_{3}$ & 1,Bs & 3,219 \\
\hline 13 & 2,6-Dimeflumafienol & $\mathrm{C}_{\mathrm{H}_{2}} \mathrm{H}_{2} \mathrm{O}_{3}$ & 5,55 & 6,202 \\
\hline 14 & C, relotme & $\mathrm{C}_{8} \mathrm{HOO}_{2}$ & 1,98 & 2,908 \\
\hline 15 & Oxirme & $\mathrm{C}_{-} \mathrm{H}_{15} \mathrm{O}$ & 1,75 & 4,900 \\
\hline
\end{tabular}

Tabel 2 Komponen penyusun asap cair tempurung kelapa

Hasil analisis tersebut menunjukkan bahwa komponen dominan penyusun asap cair tempurung kelapa adalah senyawa asam dan fenol. Komponenkomponen tersebut dapat berfungsi sebagai antirayap dan antimikroba. Semakin tinggi kandungan fenol dan asam asetat, semakin tinggi pula sifat antirayap asap cair tersebut (Yatagi et al., 2002).

\section{Hasil Observasi ke Jambi}

Observasi lapangan dilakukan di Rumah Tuo Rantau Panjang, Kabupaten Merangin, Provinsi Jambi. Rumah Tuo dibuat pada tahun 1333 M. Selain masih dihuni, rumah ini juga dijadikan museum bagi suku Batin. Suku Batin merupakan keturunan Proto Melayu. Diyakini ribuan tahun lalu nenek moyang suku Batin bermigrasi dari Cina Selatan menuju Indonesia menyusuri sungai Batanghari di Jambi menuju hulu. Rumah tradisional ini berbentuk rumah panggung. Keunikan rumah ini adalah dibangun hanya dengan menggunakan pasak dan ikat, tanpa menggunakan wawancara dengan masyarakat setempat, sebagian besar warga sudah jarang memasak dengan menggunakan tungku perapian berbahan kayu bakar. Mereka beralih memasak menggunakan bahan bakar gas. Tungku untuk memasak tradisional bagian atas sudah diganti dengan kayu baru. Awalnya bagian atas tungku adalah bamboo.

Rumah Tuo menggunakan beberapa jenis kayu yang berbeda pada tiap-tiap bagian. Pada bagian tiang dan bendul (balok kayu yang dipasang melintang pada tiang rumah untuk menyangga terbuat dari kayu kelat. Pada bagian kerangka terdiri dari kayu kulim dan kayu medang batu. Kayu kelat mempunyai ciri morfologi berwarna cokelat kemerah-merahan, kayu keras, teksturnya agak kasar, arah serat agak berpadu, permukaan kayu agak berpadu, memiliki corak polos, kelas kuat II. Kayu Kelat masuk dalam family Myrtaceae (Idris et al., 2008). Kayu Medang Batu memiliki ciri morfologi tekstur kayu agak kasar, kesan raba agak licin, mempunyai kelas awet III dan kelas kuat II, tingkat kekerasan lunak agak keras, tidak mempunyai corak yang khas. Kayu medang batu masuk ke dalam family Lauraceae (Herawati, 2008). 

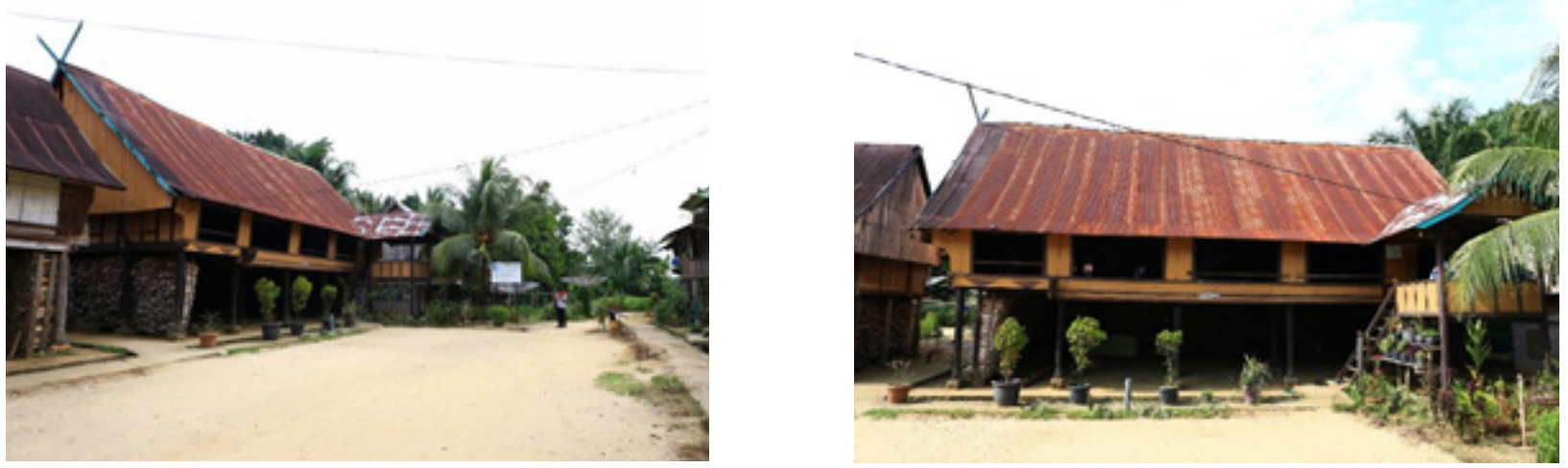

Gambar 3 Rumah tetua adat Desa Rantau Panjang

Pengawetan kayu yang pernah dilakukan oleh warga suku Batin adalah dengan mengoleskan getah pohon kayu Uba (nama lokal). Karena pohon semakin langka, suku Batin beralih dengan menggunakan cairan tembakau dan pelepah pisang untuk mengawetkan kayu bangunan rumah. Teknik tersebut di dapatkan setelah mendapatkan pelatihan dari BPCB Jambi. Kerusakan kayu struktur bangunan rumah Tuo umumnya disebabkan karena adanya beban yang terlalu berat, sehingga mengakibatkan kayu tiang terutama, mengalami retakan. Beban yang ada terdiri dari beban statis (beban yang membebani kayu secara terus-menerus) seperti semakin banyaknya barang yang ada di atas struktur kayu tersebut dan beban dinamis (beban yang membebani kayu sesaat) seperti manusia yang lalu lalang di rumah tersebut. Faktor lain yang kemungkinan menyebabkan kayu penyusun bangunan rumah Tuo mengalami pelapukan (deteriorasi) adalah faktor biologis. Banyak ditemui lichen, lumut, dan sarang hewan seperti tawon.

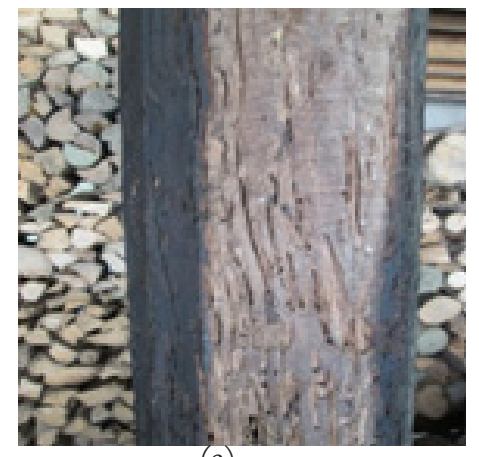

(a)

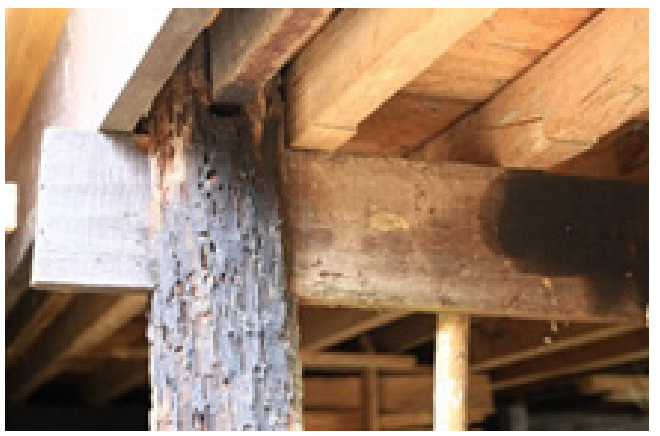

(b)

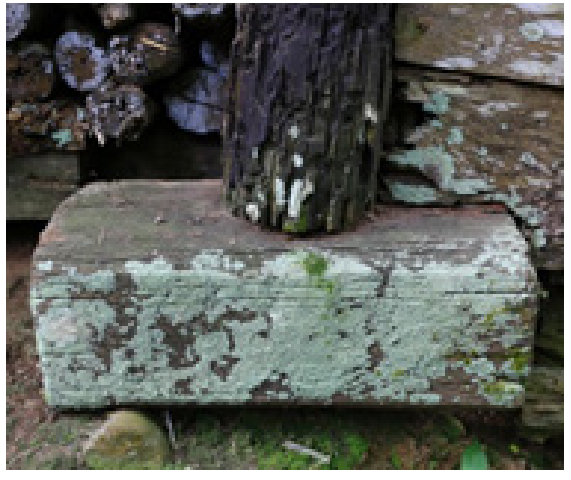

(c)

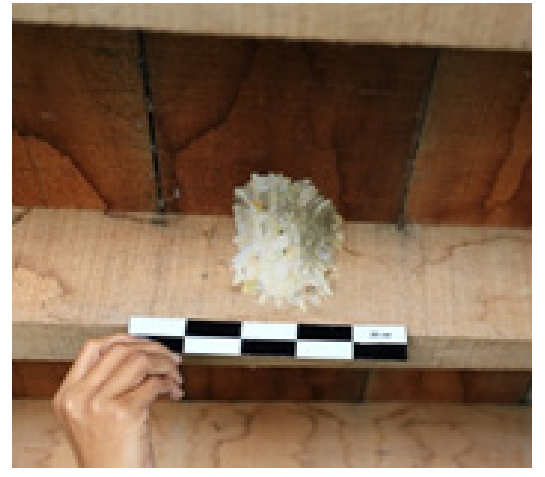

(d)

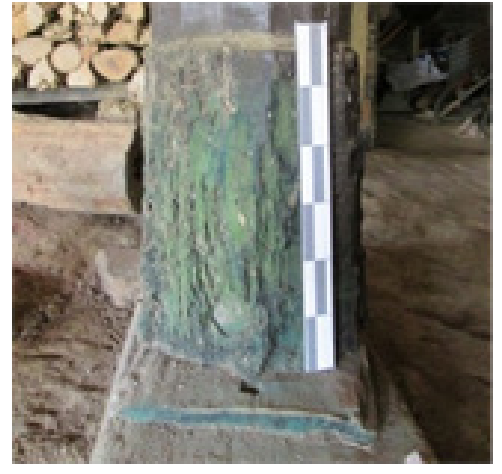

(e)

Gambar 4 Beberapa faktor yang menyebabkan degradasi kayu pada Rumah Tuo. Gambar (a) dan (b) degradasi yang diakibatkan oleh kelebihan beban. Sedangkan pelapuk biologis terdiri dari (c) Lichens; (d) sarang tawon; (e) Lumut 
Aktifitas makan rayap pada uji kubur ditunjukkan dari besar atau kecilnya nilai persentase kehilangan berat contoh uji. Berdasarkan hasil penelitian, ratarata kehilangan berat kayu Nangka \& Jati yang diamati terhadap konsentrasi asap cair cenderung menurun. Kehilangan berat tertinggi terdapat pada konsentrasi 0\% sebesar 25,52\%, sedangkan nilai terendah terdapat pada konsentrasi asap cair 100\% sebesar 15,13\% (Gambar 5)

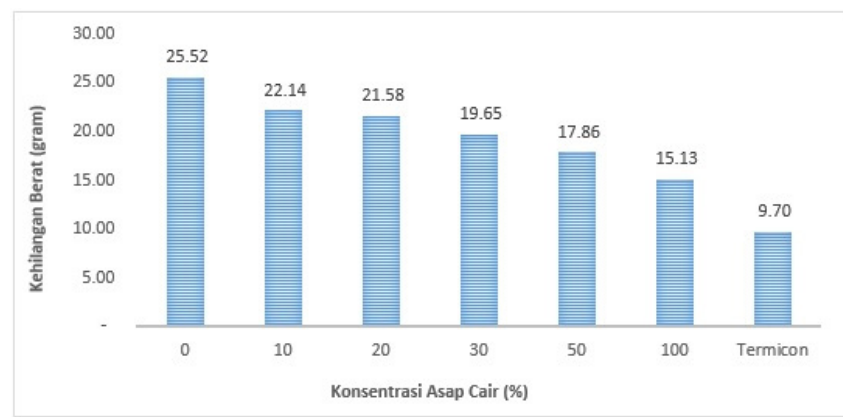

\section{Gambar 5 Kehilangan berat kayu terhadap} konsentrasi asap cair

Berdasarkan gambar 6, rata-rata nilai kehilangan berat kayu Nangka lebih rendah jika dibandingkan kayu Jati pada semua konsentrasi asap cair. Kehilangan berat kayu Nangka sebesar 35,98\%. Sedangkan kehilangan berat pada kayu Jati sebesar 39,21\%.

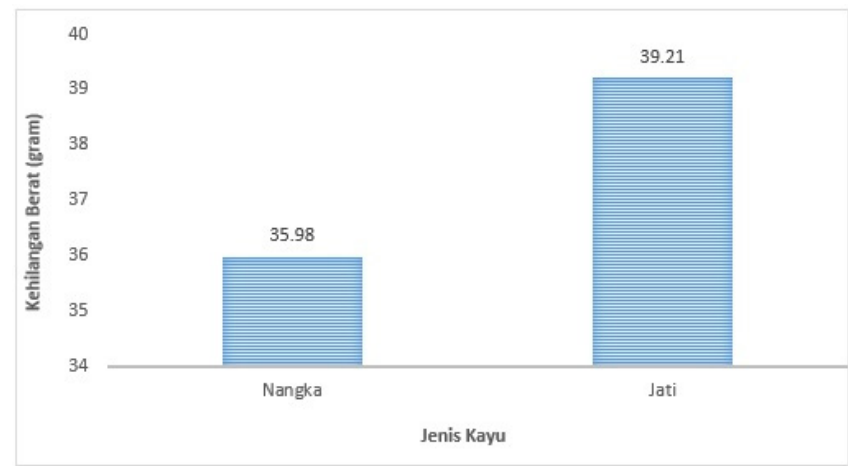

\section{Gambar 6 Kehilangan berat kayu terhadap jenis kayu}

Metode yang digunakan pada penelitian ini menunjukkan tidak berpengaruh nyata pada kehilangan berat kayu contoh uji (kayu Nangka \& Jati; semua konsentrasi asap cair). Metode oles memiliki nilai lebih rendah sebesar 37,34\% jika dibandingkan dengan metode semprot yang mempunyai nilai 37,85\% (Gambar 7).

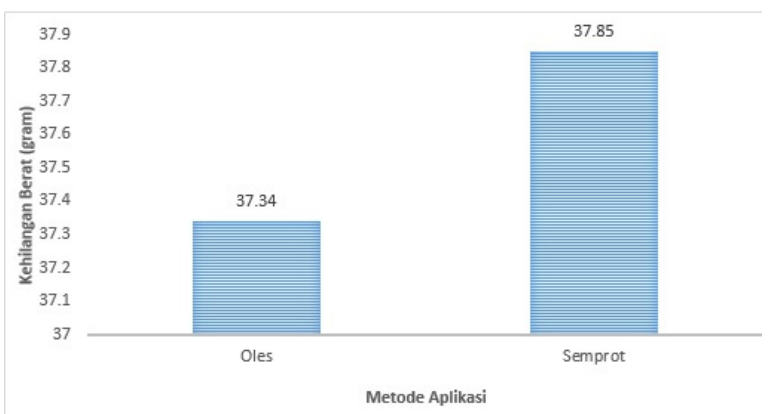

Hasil analisis sidik ragam menunjukkan konsentrasi asap cair memberikan pengaruh nyata pada selang kepercayaan 95\% (Tabel 3). Hasil uji lanjut Duncan terhadap faktor konsentrasi asap cair menunjukkan konsentrasi 100\% memiliki kehilangan berat terendah selain kontrol positif (Termicon) dan kehilangan berat tertinggi terdapat pada kontrol negatif.

Konsentrasi asap cair mempengaruhi jumlah kehilangan berat kayu terhadap serangan rayap. Hal ini disebabkan karena asap cair tempurung kelapa memiliki kandungan yang bersifat toksik yang tidak disukai oleh rayap. Komponen kimiawi asap cair yang bersifat toksik seperti fenol dan asam asetat (Maga, 1987). Semakin tinggi konsentrasi asap cair semakin tinggi pula konsentrasi yang dikandungnya, maka jumlah kehilangan berat kayu semakin rendah.

Jenis kayu tidak berpengaruh nyata terhadap kehilangan bobot contoh uji. Kayu Nangka memiliki jumlah kehilangan berat kayu lebih kecil sebesar 35,98\%, sedangkan untuk kayu Jati kehilangan berat sebesar 39,21\%. Hal ini diduga kandungan zat ekstraktif pada kayu Nangka lebih tinggi daripada kayu Jati.

Keawetan kayu dipengaruhi oleh kandungan zat ekstraktif yang bersifat toksik bagi organisme perusak kayu, sehingga organisme perusak tersebut tidak dapat masuk dan merusak kayu (Dumanaw, 1990). Zat ekstraktif bersifat menolak rayap sehingga semakin banyak zat ekstraktif dalam kayu semakin tinggi ketahanan kayu terhadap serangan rayap (Haygreen \& Bowyer, 1989). Oleh sebab itu, kayu Nangka memiliki keawetan alami lebih tinggi dibandingkan dengan Kayu Jati pada penelitian ini. 
Tabel 3 Hasil analisis sidik ragam

\begin{tabular}{|c|c|c|c|c|c|c|c|}
\hline \multirow{3}{*}{$\frac{5 x}{\text { Patl'wan }}$} & \multirow{3}{*}{ D } & \multirow{3}{*}{$\frac{\mathrm{JX}}{242.86}$} & \multirow{3}{*}{$\begin{array}{l}\mathbf{K T} \\
\mathbf{8 . 9 9}\end{array}$} & \multirow{2}{*}{\multicolumn{2}{|c|}{$\mathbf{F}_{\mathbf{*}}$}} & \multicolumn{2}{|c|}{$\mathbf{F}$} \\
\hline & & & & & & \multirow{2}{*}{405} & \multirow{2}{*}{.41} \\
\hline & & & & 2.6] & & & \\
\hline Konsationi (A) & 6 & 216.01 & 36.00 & 10.43 & $* *$ & 2265567 & 3.14269 \\
\hline 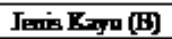 & ] & 6.07 & 6.07 & 1.76 & to & 4.012973 & $7.11000 \mathrm{~B}$ \\
\hline Metude (S) & ] & 0.15 & 0.15 & 0.04 & to & 4.012973 & 7.110008 \\
\hline $\mathbf{A B}$ & 6 & 3.51 & 1.42 & 0.41 & to & 2265567 & 3.14269 \\
\hline$\overline{\mathbf{A C}}$ & 6 & 7.60 & 1.30 & D.3 & to & 2265567 & 3.14269 \\
\hline $\mathbf{B C}$ & ] & 0.70 & 0.70 & 0.20 & to & 4.012973 & T.11000is \\
\hline$\overline{A B C}$ & 6 & 3.63 & 0.60 & 0.18 & to & 2265567 & 3.14269 \\
\hline Gallat & 56 & 19334 & 3.45 & & & & \\
\hline Tutnl & 83 & 43620 & & & & & \\
\hline
\end{tabular}

Keterangan :

** : Berpengaruh sangat nyata

* : : Berpengaruh nyata

tn : tidak berpengaruh nyata/tidak berbeda nyata

\section{Penentuan Kelas Mutu Kayu}

Penentuan kelas mutu kayu berdasarkan ASTM D 1758-06 ditentukan berdasarkan persentase penetrasi rayap dari arah cross section (Tabel 4). Semakin tinggi nilai mutu kayu semakin tahan kayu tersebut terhadap serangan rayap tanah. Hasil penentuan kelas mutu kayu tersaji pada tabel 4. Berdasarkan tabel 4, kayu yang diaplikasikan dengan asap cair kontrol menunjukkan kelas mutu kayu paling rendah, yaitu kelas mutu 6. Kelas mutu tersebut menunjukkan penetrasi rayap tanah terhadap contoh uji sebesar 30\% sampai 50\% dari penampang melintangnya. Sementara itu, kayu yang diaplikasikan dengan asap cair konsentrasi 100\% memiliki kelas mutu tertinggi yaitu 9 dimana kelas mutu tersebut menunjukkan penetrasi serangan rayap terhadap contoh uji sebesar 3\% dari penampang melintangnya.

Tabel 4 Kelas mutu kayu terhadap konsentrasi asap cair berdasarkan ASTM D 1758-06

\begin{tabular}{|c|c|c|}
\hline Kenestri & 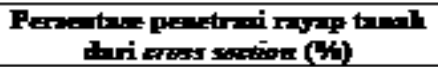 & 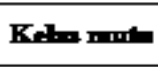 \\
\hline $\mathbf{0}$ & 3051 & 6 \\
\hline 10 & 1555 & 7 \\
\hline 20 & 954 & $\mathbf{3}$ \\
\hline 30 & 856 & $\mathbf{3}$ \\
\hline 50 & 4.92 & $\mathbf{3}$ \\
\hline 100 & 2.79 & 9 \\
\hline Temion & $\mathbf{0}$ & 10 \\
\hline
\end{tabular}

Rayap menyerang kayu untuk dijadikan sebagai tempat tinggal dan makanan (Tarumingkeng, 2001). Kerusakan yang terjadi akibat serangan rayap menunjukkan kesukaan rayap terhadap contoh uji.
Gambar 6 menunjukkan serangan rayap terparah pada kayu Jati dengan tanpa perlakuan asap cair. Hal ini menunjukkan bahwa asap cair dapat meningkatkan kualitas mutu kayu.

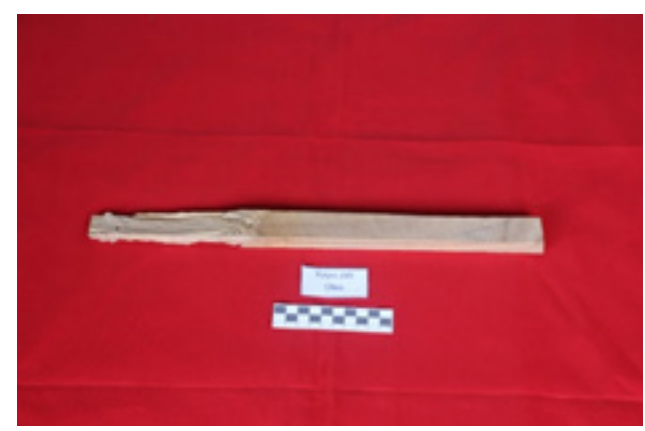

Gambar 8 Kerusakan pada kayu Jati setelah uji

Kubur

\section{Kesimpulan}

Dari ketiga variabel bebas hanya konsentrasi asap cair yang memberikan pengaruh yang nyata (selang kepercayaan 99\%) terhadap daya tahan contoh uji dari serangan rayap tanah. Semakin tinggi konsentrasi asap cair, kehilangan berat contoh uji semakin rendah. Kelas mutu yang mengacu pada ASTM D 1758-06 menunjukkan kayu yang diberikan perlakuan konsentrasi asap cair 100\% memiliki kelas mutu yang tertinggi yaitu kelas mutu 9. Untuk kayu kontrol tanpa perlakuan memiliki kelas mutu kayu terendah yaitu kelas mutu 6. Sementara untuk kayu dengan perlakuan konsentrasi asap cair 10, 20, 30, dan $50 \%$ memiliki nilai yang sama yaitu 8 . 


\section{DAFTAR PUSTAKA}

[ASTM] American Society Institut. 2006. ASTM D 1758. Standard Test Methods for Small Clear Spesimensof Timber. In Annual Book of ASTM Standard. United State:Philadelpia.

Cahyandaru, N., Parwoto, Gunawan, A. 2010. Konservasi Cagar Budaya Berbahan Kayu Dengan Bahan Tradisional. Balai Konservasi Borobudur

Darmadji, P., Oramahi, H.A., Haryadi \& Armunanto, R., 2002. Optimasi Produksi dan Sifat Fungsional Asap Cair Kayu Karet. Agritech 20 (3): 147155

Dumanaw,J.F.1990.MengenalKayu.Yogyakarta:Kanisius.

Florian, M.L. 1997. Heritage Eaters: Insect and Fungi in Heritage Collections. James \& James Publishers: London, UK.

Girard, J.P., 1992 . Technology of Meat and Meat Product Smoking. Ellis Harwood.

Haygreen, J.G. \& Bowyer, J.L. 1989. Hasil Hutan dan Ilmu Kayu. Terjemahan: Hadikusumo, S.A. Gadjah Mada University Press. Yogyakarta.

Herawati, E. 2008. Karakteristik Glulam dari Kayu Berdiameter Kecil. Tesis Institut Pertanian Bogor. Bogor.

Idris, M.M., Rachman, O., Pasaribu, R.A., Roliadi, H., Hadjib, N., Muslich, M., Jasni, Ruliaty, S., Siagian, R.M., 2008. Petunjuk Praktis Sifat-sifat Dasar Jenis Kayu Indonesia. Pusat Penelitian dan Pengembangan Hasil Hutan.

Maga, J.A., 1987. Smoke in Food Processing. CRC Press. Inc. Boca Raton. Florida. :1 -3;113-138.

Ortiz, R., Parraga, M., Carrasco, I., Vega, E., Ortiz, M., Herrera, P., Jurgens, J., Held, J., Blanchette, R.. 2014. Investigation of Biodeterioration by Fungi in Historic Wooden Churches of Chile. Microbial ecology. 67(3): 568-575

Pszczola, Donald E. 1995. Tour Highlights Production and Uses of Smoke-Based Flavors. Food Technol. 49(1);70-74.
Tarumingkeng RC. 2001. Biologi dan Perilaku Rayap. Bunga Rampai Jejak Langkah Pengabdian. Bogor: Fakultas Kehutanan IPB.

Wagiman, FX. A. Ardiansyah, \& Witjaksono. 2014. Activity of Coconut Shell Liquide Smoke as an Insecticide on Rice Brown Planthopper (Nilaparvata lugens). ARPN Journal of Agricultural and Biological Science 9: 293-296.

Wijaya, M., E. Noor, T. Tedja Irawadi, dan G. Pari. 2008. Karakterisasi Asap Cair dan Pemanfaatannya sebagai Biopestisida. Bionature,vol 9(1):34-40. ISSN1411-4720 